\title{
Medicinal Flowers- An Ayurvedic Review
}

\author{
Dr. Umakant N. Rabb*
}

Assistant Professor, Department of Dravyaguna Vijnana, Acharya Deshbhushan Ayurveda Medical College and Hospital, Shamanewadi-Bedkihal, Tal: Chikkodi, Dist: Belagavi, Karnataka, India

\begin{abstract}
DOI: $10.36348 /$ sijtcm.2019.v02i10.002 $\quad$ | Received: 02.12.2019| Accepted: 11.12.2019| Published: 20.12 .2019
*Corresponding author: Dr. Umakant N. Rabb
\end{abstract}

\section{Abstract}

Flower is the reproductive structure of the plant, which contains the active molecules called phyto-chemicals. These phyto-chemicals have potential biological activities when administered in the body, which help to eradicate the diseases and to attain health. Flower is the symbol of love and consciousness. It is one of the ultimate sources of happiness. In the yogic science each our bodily Chakra (Plexus) resembles the symbol of flower. Since Vedic period the flowers were used in the form of Pushabhisheka, Garland, and decorative purposes. The flowers too have spiritual aspects. For example Lord Bramha, Goddess Laxmi is sitting on lotus flower. Lord Buddha holds a lotus flower in his hand symbolises the Mantra "OM MANI PADME HUM". Lord Shiva likes the Dhattura (Datura metal Linn), Dronapushpi flowers for Abhisheka. Lord Vishnu likes Tulasi flowers. Lord Ganesha likes Japa Pushpa; likewise flowers are being used since Vedic period not only for ritual but also for therapeutic purpose. Here an attempt is made to explore the various types of medicinal flowers, their therapeutic actions which were dealt in Ayurvedic classical texts. Further scope of study is to cultivate such medicinal flowers and evaluate the pharmacological actions by experimentally as well as clinical trials.

Keywords: Ayurveda, Pushpa, Charaka Samhita, Sushruta Samhita, Astanga Hridaya, Nighantu etc.

Copyright @ 2019: This is an open-access article distributed under the terms of the Creative Commons Attribution license which permits unrestricted use, distribution, and reproduction in any medium for non-commercial use (NonCommercial, or CC-BY-NC) provided the original author and source are credited.

\section{INTRODUCTION}

Flower is the reproductive structure of the plant, which contains the active molecules called phytochemicals. These phyto-chemicals have potential biological activities when administered in the body and also help to eradicate the diseases and to attain health. Flower is the symbol of love, beauty and consciousness. It is most attractive part of the plant and also liked by animal beings. Since Vedic period flowers were using for various health ailments, various rituals and also for cosmetic purposes. The Charaka Samhita explains the group of drugs which mainly contain flowers and which are used for eliminating the abnormal colours of the urine, stool, retaining stools i.e anti-diarrhoeal, flowers eliminating Daha (Burning sensation). Acharya Sushruta also mentioned some group of drugs. In these groups the flowers are being used for various diseases. Viz; Utpaladi Gana -This group is similar to the group of Mutravirajaniya Gana of Charaka Samhita.

\section{DISCUSSION}

In Charaka Samhita [1] the therapeutic uses of flowers are described in the following groups.

1. Mutravirajaniya Gana- The drugs which eliminates the abnormal colour of the urine. This group contains flowers such as Padma, Utpala,
Nalina, Kumuda, Saugandhika, Pundarika, Shatapatra, Madhuka, Priyangu, and Dhataki.

2. Purishasangrahaniya Gana- The drugs which retains the stool called as anti diarrhoeal. This group contains Dhataki Pushpa and Stamens of the Kamala.

3. Purishavirajaniya Gana- The drugs which eliminates the abnormal colour of the stool. The flowers in this group are Madhuka and Utpala.

4. Dahaprashamana Gana- The drugs which pacifies the heat and burning sensation. The flowers are Madhuka and Neelotpala

In Sushruta Samhita [2] the flowers are included in these groups. Viz

1. Utpaladi Gana- The drugs are similar to the Mutravirajananiya of Charaka Samhita. This group subsides Daha(Burning senation), RaktaPitta diseases, Thrishna(Thirst), Visha(Poison effects), Hrit(Heart diseases), Chardi(Vomiting), Murcha(Fainting).

2. Anjanadi Gana- The flowers of this group are Nagapushpa, Priyangu, Neelotpala, stamens of Kamala.

3. Priyangwadi Gana- Tis group includes Dhataki, Punnaga, Nagapushpa, stamens of Kamala. 
4. Ambasthadi Gana- This group contains Dhataki and stamens of Kamala.

The Priyangwadi and the Ambasthadi Ganas are alleviates Atisara(diarrhoea), Sandhanakara(Heals the fractures.).

5. Sarivadi Gana- It includes Madhuka flowers. This particular group alleviates Thrishna (Thirst), Rakta-Pitta (Heamorrhage), Pittaja Jwara (Fever due to Pitta Dosha) associated with Daha (Burning sensation).

6. Eladi Gana- This group includes Keshara and stamens of Punnaga. This group alleviates VataKapha Dosha, Visha (Poison effects), Kantiprada (Improves complexion), Kusthagna (Skin diseases), Kandu (Itching sensation), Sheetapitta (Urticaria).

7. Pittasamshamana Gana [3] - This group includes Padma, Utpala, Nalina, Kumuda, Saugandhika, Pundarika, Shatapatra, Madhuka, Priyangu and Dhataki.

\section{Therapeutic uses of Pushpa (Flowers)-}

- AGASTYA PUSHPA (Sesbenia grandiflora Pers) [4-6] - The Agastya Pushpa is Tuvara (Astringent), Tikta(Bitter), Sheeta(Cold) in potency, PittaKapha-Asr Shantikrit(Subsides Pitta, Kapha and Rakta Doshas).

- AGNIMANTHA PUSHPA(Premna mucranata Roxb $)^{[7],[8],[9]}$ - The Angimantha Pushpa is Hridya(Good for heart), Sara(Laxative), Tridosha shaman(Subsides all the three Doshas), Alleviates Adhmana(Flatulence), Chardi(Vomiting), Shotha(Edema), Chakshuroga(Eye diseases), Vishapaha(Poisonous effects).

- MADHAVI PUSHPA(Hiptage benghalensis Kurz) [10, 11] - The Madhavi Pushpa is Kashaya(Astringent) in taste, Hima(Cold) in potency, Subsides Pitta, Daha(Burning sensation), Jwara(Fever), Hikka(Hiccough), Unmada(Euphoria), Shrama(Lethargy).

Chardi(Vomiting),

AMLIKA PUSHPA (Tamarindus indica Linn) [12] - The Amlika Pushpa is Swadu (Sweet) in taste, Kashaya (Astringent), Amla(Sour), Ruchiprada(Promotes taste), Mehagna (Cures urinary diseases including diabetes), Agnijanana(Appetizer), Laghu(Light), subsides Vata and Kapha Doshas.

- ARKA PUSHPA(Calotropis procera(Ait) R.Br) [13],[14] - Arka Pushpa is Madhura(Sweet) , Tikta(Bitter) in taste, Subsides Kustha(Skin diseases), Krimi(Worms), Kapha, Akhorvisha(RatPoisoning), Raktapitta(Haemorrhage), Shopha (Edema), Gulma(Visceral organ diseases).

- ALARKA PUSHPA (Calotropis gigantean(Linn), R.Br.exAit) [15] - The Alarka Pushpa is $\operatorname{Laghu}($ Light $)$, Vrishya(Aphrodisiac), Deepana(Appetizer), Pachana(Digestive), Alleviates Arochaka(Loss of appetite),
Praseka(Exess salivation), Arsha(Haemorrhoids), Kasa(Cough), Shwasa(Dyspnoea).

- ASHOKA PUSHPA (Saraca asoca roxb. De Wilde) [16] - The Ashoka Pushpa is Kashaya(Astringent), Hima(Cold) in potency, Tikta(Bitter), Grahi(Absorbent), Varnya(Improves complexion), It subsides Trisha(Thirst), Daha(Burning sensation), Raktapitta(Haemorrhage).

- ASANA PUSHPA (Pterocarpus marsupium Roxb) [17, 18] - The Asana Pushpa is Tikta (Bitter) in taste, Madhura Vipaka (Sweet) in post digestive effect, Kapha-Pittahara (Subsides Kapha and Pitta Doshas).

- AMRA PUSHPA (Mangifera indica Linn) [19] The Amra Pushpa is Kashaya (Astringent), Grahi (Absorbent), Rochana (Promotes taste), KaphaPittahara (Subsides Kapha and Pitta Dosha). It is used in Prameha (Urinary diseases including diabetes), Atisara (Diarrhea), Asrag (Blood diseases).

- ARAGWADHA PUSHPA (Cassia fistula Linn) [20, 21] - The Aragwadha Pushpa is Kashaya (Astringent), Hima (Cold in potency), Swadu (Tasty), Sangrahi (Absorbent), Tikta (Bitter) in taste, Manojnya (Charming/ Beautiful).

- AVARTAKI PUSHPA (Cassia auriculata Linn) [22] -The Avartaki Pushpa is Kashaya (Astringent), Tikta (Bitter) in taste, possess yellow colour flower, Alleviates Prameha (Urinary diseases including diabetes), Krimi (Worms), Kustha(Skin diseases).

- INGUDI PUSHPA (Balanites aegyptiaca (Linn) Delile) [23] -The Ingudi Pushpa is Ushna(Hot in potency), Snigdha(Demulcent), Swadu(Sweet), Tikta(Bitter) in taste, Subsides Vataja diseases, Krimi(Worms), Shleshma(Kapha Doshas), Vrina Ropana(Heals the wounds and ulcers).

- UTPALA-

1. Kumuda (Nymphaea nouchali Burm.f) [24] Kumuda is Swadu (Sweet), Tikta (Bitter) in taste, Sheetala(Cold in potency), Swadu Paka(Sweet in post digestive effect). Subsides Kapha and Pitta diseases, Rakta Dosha (Blood diseases), Daha (Burning sensation), and Shrama (Exertion).

2. Neelotpala (Nymphaea stellata Willd) [25-27] Neelotpala Pushpa is Swadu(Sweet), Tikta(Bitter) in taste, Madhura Viapaka(Sweet in post digestive effect), Surabhi(Aromatic), Sheeta(Cold in potency), Vishada(Non-slimy), Hridya(Cardio tonic), alleviates Raktapitta(Haemorrhage), Daha(Burning sensation).

- ERANDA PUSHPA (Ricinus communis Linn) [28] - The Eranda Pushpa is Ushna (Hot in potency), Vatagna(Subsides Vata), Katu (Pungent), Tikta(Bitter in taste). Alleviates Vata and Kapha Doshas, Mutragada (Urinary diseases). Aggravates Rakta and Pitta Dosha. 
- KADAMBA PUSHPA (Anthocephalus indicus Miq) [29]- Bhav prak nigh pushpa varga shloka no36, p.no-324] -------- The Kadamba Pushpa is Swadu(Sweet), Kashaya(Astringent), Lavana(Salty) in taste, Guru(Heavy), Sara(Laxative), Ruksha(Dry), Visthambhakrit(Produces flatulence), KaphaVatakara(Aggravates Kapha and Vata Dosha), Stanyaprada(Galactogogue).

- KADALI PUSHPA (Musa paradisiacal Linn) [30]- The Kadali Pushpa is Swadu(Sweet), Tikta(Bitter), Kashaya(Heavy), Guru(Heavy), Sheeta(Cold in potency), KaphaPittahara(Subsides Kapha and Pitta Doshas). Alleviates Rakatapitta (Haemorrhage), Kshaya (Emaciation).

- KAPITTHA PUSHPA (Feronia limonia (Linn) Swingle) [31] - The Kapittha Pushpa is Kashaya (Astringent), Tikta (Bitter), Sheeta (Cold in potency), Visha Nashana (Subsides poisonous effects). It is significantly used in Rat Poison.

- KAMALA PUSHPA (Nelumbo nucifera Gaertn) [32, 33] - The Kamala Pushpa is Madhura (Sweet), Tikta (Bitter), Kashaya (Astringent) in taste, Sheeta (Cold in potency). Alleviates Raktapitta (Haemorrhage), Daha (Burning sensation), Thrishna (Thirst). The flower stalk of Kamala is Madhura (Sweet) in taste, Sheeta (Col in potency), Ruksha (Dry), Durjara (Difficult to digest). It alleviates Pitta Dosha, Daha (Burning sensation, Asr (Blood diseases), Stanyaprada (Promotes lactation). It increases Vata and Kapha Doshas. The Stamens and pollens of Kamala are Kashaya (Astringent), Swadu (Sweet in taste), Ruksha(Dry), Sheeta(Cold in potency). It subsides Kapha, Pitta Doshas, Thrishna(Thirst), Daha(Burning sensation), Raktapitta(Haemorrhage), Raktarsha(Bleeding piles), Visha(Poisonous effects), Shotha(Edema).

- KARIRA PUSHPA (Capparis deciduas Edgew) ${ }^{[34]}$ -The Karira Pushpa is Kashaya(Astringent), Bhedi(Purgative). It aggravates Vata and subside Kapha and Pitta Dosha.

- KANCHANARA-KOVIDARA PUSHPAKANCHANARA PUSHPA (Bauhinia variegate Linn), -KOVIDARA PUSHPA (Bauhinia purpurea Linn $)^{[35],[36]}$ - The Kanchanara and Kovidara Pushpa is Kashaya(Astringent), Swadu(Sweet) in taste, Madhura Vipaka(Sweet in post digestive effect), Guru(Heavy), Sheeta(Cold in potency), Rochani(Tasty), Ruksha(Dry). It alleviates Shwasa (Dyspnoea), Kasa (Cough), Kshaya (Emaciation), Raktapitta (Haemorrhage), Pradara (Dysmenorrhoea).

- KASAMARDA PUSHPA (Cassia occidentalis Linn) [37] - The Kasamarda Pushpa alleviates Shwasa (Dyspnoea), Kasa (Cough), Urdhwa Anila (Upward movement of the Vayu).

- KUMKUMA PUSHPA (Crocus sativus Linn) [38] - The Kumkuma is Katu(Pungent), Tikta(Bitter) in taste, Ushna(Hot in potency), Shleshma Samirajit(Subsides Kapha and Vata), Vrina(Wound), Drishthi(Eye diseases), Shiro Roga(Diseases of head), Visha(Poison effect), Kayakanti Krit(Improves complexion and lustre of the body).

- KUTAJA PUSHPA (Holarrhena antidysenterica (Linn) Wall) [39, 40] - The Kutaja Pushpa is Laghu (Light), Kashaya (Astringent), Tikta (Bitter) in taste, Sheeta (Cold in potency), Sangrahi (Absorbent). It subsides Pitta, Asr (Blood), Kapha Doshas. It cures Kustha (Skin diseases), Hridroga (Heart diseases), Atisara (Diarrhea), Jwara (Fever), Udavarta (Upward movement of the Vata), Udara (Abdominal diseases).

- KUNDAM PUSHPA (Jasminum multiflorum Andr) [41] - The Kunda Pushpa is Laghu (Light), Sheeta (Cold in potency). It subsides Kapha and Pitta Doshas, Shiroroga (Diseases of head), Visha (Poison effects).

- KUBJAKAM PUSHPA (Rosa moschata Herrm) [42] - The Kubjaka Pushpa is Surabhi (Aromatic), Swadu (Sweet), Kashaya (Astringent) in taste, Laghu (Light), Sheeta (Cold in potency). Subsides Kapha and Pitta Doshas, Varnya (Improves complexion), Dahaprashaana (Alleviates burning sensation).

- KUMARI PUSHPA (Aloe vera Tourn ex Linn) [43] - The Kumari Pushpa subsides Vata and Pitta Doshas, Krimi (Worms).

- KURANTAKA PUSHPA (Barleria prionitis Linn) [44] -The Kurantaka Pushpa subsides Kapha and Pittaja diseases.

- KETAKI PUSHPA (Pandanus odoratissimus Roxb) [45] -The Ketaki Pushpa is Katu (Pungent), Tikta (Bitter) in taste, Ushna (Hot in potency). It subsides Vata-Kapha, Visha (Poison effect), Kantijanan (Improves complexion), Daha and Durgandha Nashana (Alleviates burning sensation and foul smell).

- GAMBHARI PUSHPA (Gmelina arborea Linn) [46] - The Gambhari Pushpa is Madhura (Sweet), Tikta (Bitter), Kashaya (Astringent) in taste, Sheeta (Cold in potency), Sangrahi(Absorbent), Vatala(Aggravates Vata Dosha). It subsides Raktapitta (Haemorrhage).

- CHAMPAKA PUSHPA (Michelia champaka Linn) [47, 48] - The Champaka Pushpa is Laghu(Light), Grahi(Absorbent), Tikta(Bitter), Kashaya(Astringent), Madhura(Sweet) in taste, Hima(Cold in potency). Subsides Kapha and Pitta Doshas, Visha (Poison effects), Kustha (Skin diseases), Vrina (Heals the wound).

- JATI PUSHPA (Jasminum officinale Linn) [49] The Jati Pushpa is Tikta (Bitter), Ushna (Hot in potency), Kashaya(Astringent), Laghu(Light). It subsides Vata, Shiro Rogas(Diseases of head), Mukha(Mouth), Danta(Teeth), Visha(Poison), Kustha(Skin diseases), Vrina(Wounds), Asr(Blood diseases). 
- JEEVANTI PUSHPA (Leptadenia reticulate W \& A) [50] - The Jeevanti Pushpa is Kashaya (Astringent), Madhura (Sweet) in taste, Laghu (Light), Pathya(Cleanses the channels), Ruchikara(Appetizer), Vrushya(Aphrodisiac), and subsides Kapha and Pitta Doshas.

- TILAKA PUSHPA (Wendlandia exerta DC) [51] The Tilaka Pushpa is Katu (Pungent), Ushna (Hot in potency), alleviates Kapha and Vata Doshas, Netra Roga(Eye diseases), Krimi(Worms).

- TULASI PUSHPA (Ocimum sanctum Linn) [52] The Tulasi Pushpa is Katuka (Pungent), Tikta (Bitter), Ushna (Hot in potency), Dipana (Appetizer), Hridya (Cardio tonic), Pittakara (Aggravates Pitta Dosha). It alleviates Daha (Burning sensation), Kustha (Skin diseases), Krachra (Dysuria), Asr (Blood diseases), Parshwaruk (Pain in flanks), Kapha and Vata.

- DADIMA PUSHPA (Punica granatum Linn) [53] - The Dadima Pushpa is Grahi (Absorbent), Hima(Cold in potency), Bala Atisarajit(Cures diarrhoea in children), The juice of this flower instilled in case of cures nasal bleeding.

- DHATAKI PUSHPA (Woodfordia fruticosa Kurz) [54,55] - The Dhataki Pushpa is Kashaya(Astringent), Sheeta(Cold in potency), Madakrit(Causes drowsiness), Laghu(Light). Cures Trishna (Thirst), Krimi (Worms), Visha (Poison effects), Raktapitta (Haemorrhage), Atisara(Diarrhoea).

- NAGA PUSHPA (Mesua ferrea Linn) [56]- The Naga Pushpa is Kashaya(Astringent), Tikta(Bitter), Alpa Ushna(Slightly hot in potency), Laghu(Light). Alleviates Kapha-Pitta Doshas, Visha (Poison effects), Rakta Rodhaka (Acts as haemostatic).

- NARIKELA PUSHPA (Cocos nucifera Linn) [57] -It alleviates Raktatisara (Diarrhoea with blood), Raktapitta (Haemorrhage), Prameha (Urinary diseases including diabetes).

- NIMBA PUSHPA (Azadirachta indica A. Juss) [58] -The Nimba Pushpa is Sheeta (Cold in potency), Sangrahi (Absorbent). It is Chakshushya (Good for eyes), Vatala (Aggravates Vata Dosha), Katu Paka (Pungent in post digestive effect), Visha (Poison effects), Sarva Arochaka Nashaka (Cures all types of anorexia).

- NIRGUNDI PUSHPA (Vitex negundo Linn) [59] The Nirgundi Pushpa is Tikta (Bitter), Ushna (Hot in potency), Katu (Pungent). It alleviates Krimi (Worms), Pleeha (Enlargement of spleen), Aruchi (Anorexia), Kustha(Skin diseases), Kandu(Itching), Shopha(Edema).

- NEPALIKA PUSHPA (Jasminum species) [60] The Nepalika Pushpa is Tikta(Bitter) in taste, Ushna(Hot in potency), subsides Vata Pitta Doshas, Ruja(Pain), Netra Rogas(Eyes diseases).

- PANASA PUSHPA (Artocarpus heterophyllus Lam)[61] - The Panasa Pushpa is Tikta(Bitter), Guru(Heavy), Vaktra Vishodhanam(Cleanses mouth).
- PALASHA PUSHPA (Butea monosperma (Lam) Kuntze)[62] - The Palasha Pushpa is Kashaya(Astringent), Tikta(Bitter), Madhura(Sweet) in taste, Sheeta (Cold in potency), Grahi(Absorbent), alleviates Kustha(Skin diseases), Daha(Burning sensation), Thrishna(Thirst).

- PATALA PUSHPA (Stereospermum suaveolens DC)[63] -The Patala Pushpa is Kashaya(Astringent), Swadu(Sweet) in taste, Hima(Cold in potency), Hridya(Cardio tonic). It subsides Kapha, Rakta diseases, Atisara(Diarrhoea), Daha(Burning sensation). These flowers are used for flavouring the water.

- PARIBHADRA PUSHPA (Erythrina indica Linn)[64] -The Paribhadra Pushpa is Kashaya(Astringent) in taste. It alleviates Pitta and Karna Rogas(Ear diseases).

- PRIYANGU PUSHPA (Callicarpa macrophylla Vahl)[65] - The Priyangu Pushpa is Tikta(Bitter), Sheeta(Cold in potency). It alleviates aggravated Rakta (Blood), Moha (Confusion), Daha (Burning sensation), Jwara (Fever), Vamana (Vomitting). It is one of the Shonita Sthapana (Haemostatic).

- BAKULA PUSHPA (Mimusops elengi Linn)[66, 67] -The Bakula Pushpa is Kashaya(Astringent), Swadu(Sweet), Surabhi(Aromtic), Sheeta(Cold in potency), Grahi(Absorbent), Ruchya(Palatable). It subsides Kapha, Pitta, Rakta diseases, Visha (Poison), and Krimi (Worms).

- BADARA PUSHPA (Zizyphus jujuba Lam)[68] The Badara Pushpa is Kustagna(Subsides Skin diseases), Kapha-Pittahara(Pacifies Kapha and Pitta Doshas).

- BANDHUKA PUSHPA (Pentapetes phoenicea Linn)[69] - The Bandhuka Pushpa is Laghu(Light), Snigdha(Demulcent), Kaphapaha(Increases Kapha and subsides Vata-Pitta Doshas), Grahi(Absorbent), Jwaragna(Cures fever), Bhuta Nashana(Alleviates external evil spirits).

- BIMBI PUSHPA (Coccinia indica W. \& A.)[70] The Bimbi Pushpa is Red in colour, Tikta(Bitter) in taste, cures Prameha(Urinary diseases including diabetes), Pitta Dosha, Kamala(Jaundice).

- BILVA PUSHPA (Aegle marmelos Corr)[71] - The Bilva Pushpa is Kashaya(Astringent), Tikta(Bitter) in taste, Sangrahi(Absorbent), Dipana(Appetizer). It subsides three Doshas(Vata-Pitta-Kapha), Atisara(Diarrhea), Trhisha(Thirst), $\operatorname{Vami}$ (Vomitting).

- MADHUKA PUSHPA (Madhuka indica J.F.Gmel)[72]- The Madhuka Pushpa is Madhura(Sweet) in taste, Sheeta(Cold in potency), Balya(Tonic), Shukrakara(Increases semen), VataPitta Nashana(Subsides Vata and Pitta Doshas).

- MALLIKA PUSHPA (Jasminum sambac Ait)[73] - The Mallika Pushpa is Laghu(Light), Vrushya(Aphrodisiac), Tikta(Bitter), Katu(Pungent) in taste, Kapha-Vatahara(Subsides Kapha and Vata Dosha), cures Mukha 
Roga(Diseases of mouth), Netra(Eye), Kushta(Skin diseases), Aruchi(Anorexia), Visha(Poison), $\operatorname{Vrina}$ (Wounds).

- MATULUNGA PUSHPA (Citrus medica Linn)[74] - The Matulunga Puspa is Rochana(Tasty), Grahi(Absorbent), Sheetala(Cold in potency), Laghu(Light). It subsides Vata and Raktapitta(Haemorrhage).

- MUCHAKUNDA PUSHPA (Pterospermum acerifolium Willd)[75] -The Muchakunda Pushpa is yellow in colour. It cures Shirashoola (Headache), Pittasr(Haemorrhage), Visha(Poison effect).

- MUSHKAKA PUSHPA (Schrebera swietenioides Roxb) [76, 77]- The Mushkaka Pushpa is Kapha and Pitta Shamaka(Pacifies Kapha and Pitta Doshas), Kustha(Skin diseases).

- MOOLAKA PUSHPA (Raphanus sativus Linn)[78] - The Moolaka Pushpa is Kapha-Pitta Nashaka (Subsides Kapha and Pittaja diseases).

- YUTHIKA PUSHPA (Jasminum auriculatum Vahl)[79, 80] - The Yuthika Pushpa is Tikta(Bitter), Madhura(Sweet), Kashaya(Astringent) in taste, Katu Vipaka(Pungent in post digestive effect), Sheeta(Cold in potency), Hridya(Good for heart), Pittagna(Subsides Pitta Dosha), Kapha-Vatala(Aggravates Kapha and Vata Doshas). It cures Vrina (Wound), Mukha (Mouth), Danta(Teeth), Akshi(Eye), Shira(Head) diseases, Visha(Poison effect), Thrishna(Thirst), Kustha(Skin diseases).

- LAVANGA PUSHPA (Syzygium aromaticum (Linn) Merr and Per)[81] - The Lavanga Pushpa is Hridya(Cardio tonic), Sheetala(Cold in potency), pacifies Pitta Dosha, Chakshushya(Good for eye diseases), Vishahrit(Subsides Poison effects), Vrishya(Aphrodisisac), Mangalya(It is auspicious), Moordharogahrit(Cures diseases of head).

- LODHRA PUSHPA (Symplocos racemosa Roxb)[82] -The Lodhra Pushpa is Kashaya(Astringent), Madhura(Sweet), Tikta(Bitter) in taste, Hima(Cold in potency), Katu Vipaka(Pungent at post digestive effect), Sangrahi(Absorbent), Kapha-Pittahara(Subsides Kapha and Pitta Doshas).

- VARUNA PUSHPA (Crataeva nurvala BuchHam)[83]- The Varuna Pushpa is Kashaya(Astringent), Tikta(Bitter), Laghu(Light), Grahi(Absorbent). It alleviates Kapha-Pitta-Rakta Doshas and helps to digest the Ama(Immature or uncooked or immature food).

- VASA PUSHPA (Adhatoda vasica Nees)[84],[85] - The Vasa Pushpa is Tikta(Bitter), Katu Vipaka(Pungent at post digestive effect). It subsides Kapha and Pitta Doshas, and cures Kasa(Cough), Shwasa(Dyspnoea), Kshaya(Tuberculosis).

- SHANA PUSHPA (Crotalaria juncea Linn)[86] The Shana Pushpa is Sheeta Virya(Cold in potency), Ruchya(Tasty), Swadu(Sweet) in taste,
Sara(Laxative). It alleviates Pitta, Rakta Doshas, and Raktapitta(Haemorrhage).

- SHATAPATRI PUSHPA (Rosa centifolia Linn)[87],[88] - The Shatapatri Pushpa is Hima(Cold in potency), Tikta(Bitter), Madhura(Sweet) in taste, Sara(Laxative), Hridya(Cardio tonic). It alleviates Kustha(Skin diseases), Daha(Burning sensation), Pitta, Rakta Dosha, Varnya(Improves complexion).

- SHALLAKI PUSHPA (Boswellia serrata Roxb)[89] - The Shallaki Pushpa is a gum-resin (Kunduru), It alleviates Kapha-Vata Doshas, Rakta Dosha(Blood diseases), Kustha(Skin diseases), Aruchi(Anorexia).

- SHAKA PUSHPA (Tectona grandis Linn. f)[90, 91]- The Shaka Pushpa is Kashaya(Astringent), Tikta(Bitter), Ruksha(Dry), subsides Prameha(Uriniary diseases including diabetes ), Kapha and Pitta Doshas and aggravate Vata Dosha.

- SHALMALI PUSHPA (Salmalia malabarica Schott. \& Endl)[92] - The Shalmali Pushpa is Tikta(Bitter), Kashaya(Astringent), Swadu(Sweet at the post digestive effect), Grahi(Absorbent), Hima(Cold in potency), Kapha-PittaAsrjit(Subsides Kapha- Pitta and Rakta Doshas). The Vegetables of Shalmali flowers prepared in ghee and Saindhava Lavana (Rock salt) and given in Pradara Roga (Leucorrhoea).

- SHIGRU PUSHPA (Moringa oleifera Lam)[93, 94] - The Shighru Pushpa is Teekshna(Penetrating), Ushna(Hot in potency), Katu(Pungent) in taste, subsides Kapha and Vata Doshas. It alleviates Snayu Shotha (Neuritis), Krimi (Worms), Shotha (Edema), Pleeha(Spleenomegaly), Gulma(Visceral organ diseases).

- MADHU SHIGRU (Moringa concanensis Nimmo) [95]- The Madhu Shigru subsides Kapha and Pitta Doshas, Chakshushya(Good for eyes), Raktapittahara(Haemorrhage).

\section{CONCLUSION}

By the above discussion the flowers are the integral part of Dravyaguna Vijnana(Indian Pharmacology) and highlighted the medicinal values which helps in the alleviating the diseases and maintains the health of the person. The clinical application is well explained in the Ayurvedic classical texts. This could be the new research area one should concentrate on the potent medicinal flowers. Further scope of study is to cultivate such medicinal flowers and evaluate their pharmacological actions by experimentally as well as clinical trials.

\section{REFERENCES}

1. Acharya, C., Charaka, S. (2002). Sutrasthana $4^{\text {th }}$ chapter, Shloka No-34,35 Charaka Chandrika Hindi commentary of Agnivesha, edited by Dr. 
Bramhananda Tripathi, Chaukhamha Surabharati Prakashana, Varanasi, Reprint, 90.

2. Acahrya, S., Sushruta, S. (2002). Purvardha, Sutrasthana $38^{\text {th }}$ chapter, Shloka No41,47,46,39,24, Ayurveda Tatva Sandipika, Hindi commentary, edited by Kaviraja Dr. Ambikadatta Shastry, Chaukhamba Sanskrit Samsthan, Varanasi, Reprint, 187.

3. Acahrya, S., Sushruta, S. (2004). Purvardha, Sutrasthana $39^{\text {th }}$ chapter, Shloka No-8, Ayurveda Tatva Sandipika, Hindi commentary, edited by Kaviraja Dr. Ambikadatta Shastry, Chaukhamba Sanskrit Samsthan, Varanasi, Reprint, Page No191.

4. Acahrya, S., Sushruta, S.(2008). Purvardha, Sutrasthana $46^{\text {th }}$ chapter, Shloka No-282, Ayurveda Tatva Sandipika, Hindi commentary, edited by Kaviraja Dr. Ambikadatta Shastry, Chaukhamba Sanskrit Samsthan, Varanasi, Reprint, Page No266.

5. Acharya, K., Kaiyadeva, N., Oshadhi, V. (1979). Shloka No- 940, redacted by Sharma P.V., 1st edition, New-Delhi, Chaukhambha publications, 174.

6. Acharya Bhavamishra of Bhavaprakasha Nighantu. (2006). Pushpa Varga, Shloka No-61, by Dr. Bulusu Sitaram, Volume 1, Chaukhambha Orientalia, Varanasi, First edition, 333.

7. Pandit, N., Raj, N., Prabhadradi, V. (2003). Shloka No- 22-25, redacted by Indradeva Tripathi, Varanasi, Chaukhamba Krishnadas Academy, 268.

8. Acharya Bhavamishra of Bhavaprakasha Nighantu. (2006). Pushpa Varga, Shloka No-23-24, by Dr. Bulusu Sitaram, Volume 1, Chaukhambha Orientalia, Varanasi, First edition, 234.

9. Acharya, K., Kaiyadeva, N., Oshadhi, V. (1979). Shloka No- 27, redacted by Sharma P.V., 1st edition, New-Delhi, Chaukhambha publications, 8.

10. Pandit, N., Raj, N., Karaviradi, V. (2003). Shloka No- 94, redacted by Indradeva Tripathi, Varanasi, Chaukhamba Krishnadas Academy, 316.

11. Acharya Bhavamishra of Bhavaprakasha Nighantu, Pushpa Varga. (2006). Shloka No-41, by Dr. Bulusu Sitaram, Volume 1, Chaukhambha Orientalia, Varanasi, First edition, 326.

12. Acharya, K., Kaiyadeva, N., Oshadhi, V. (1979). Shloka No- 364, redacted by Sharma P.V., 1st edition, New-Delhi, Chaukhambha publications, 68.

13. Acharya, K., Kaiyadeva, N., Oshadhi, V. (1979). Shloka No- 1535 , redacted by Sharma P.V., 1st edition, New-Delhi, Chaukhambha publications, 630.

14. Acahrya, S., Sushruta, S., Purvardha, Sutrasthana $46^{\text {th }}$ chapter, Shloka No-284, Ayurveda Tatva Sandipika, Hindi commentary, edited by Kaviraja Dr. Ambikadatta Shastry, Chaukhamba Sanskrit Samsthan, Varanasi, Reprint, Page No-266.

15. Acharya, K., Kaiyadeva, N., Oshadhi, V. (1979). Shloka No- 1536, redacted by Sharma P.V., 1st edition, New-Delhi, Chaukhambha publications, 630.

16. Acharya Bhavamishra of Bhavaprakasha Nighantu. (2006). Pushpa Varga, Shloka No-48, by Dr. Bulusu Sitaram, Volume 1, Chaukhambha Orientalia, Varanasi, First edition, 328.

17. Acahrya Sushruta, Sushruta Samhita, Purvardha, Sutrasthana $46^{\text {th }}$ chapter, Shloka No-284, Ayurveda Tatva Sandipika, Hindi commentary, edited by Kaviraja Dr. Ambikadatta Shastry, Chaukhamba Sanskrit Samsthan, Varanasi, Reprint, Page No266.

18. Acharya Kaiyadeva, Kaiyadeva Nighantu, Oshadhi Varga. (1979). Shloka No- 814, redacted by Sharma P.V., 1st edition, New-Delhi, Chaukhambha publications, 151.

19. Acharya Kaiyadeva, Kaiyadeva Nighantu, Oshadhi Varga. (1979). Shloka No- 338, redacted by Sharma P.V., 1st edition, New-Delhi, Chaukhambha publications, 64.

20. Acharya Kaiyadeva, Kaiyadeva Nighantu, Oshadhi Varga. (1979). Shloka No- 946, redacted by Sharma P.V., 1st edition, New-Delhi, Chaukhambha publications, Page No- 174.

21. Bhagwan, D., Madanapal, N.(1991). $8^{\text {th }}$ Chapter, Abhayadi Varga, Shloka No- 123, B. Jain publisher's pvt. Ltd, first edition, New Delhi, 41

22. Acharya, K., Kaiyadeva, N., Oshadhi, V.(1979). Shloka No- 889-891, redacted by Sharma P.V., 1st edition , New-Delhi, Chaukhambha publications, 165.

23. Acharya, K., Kaiyadeva, N., Oshadhi, V. (1979). Shloka No- 865-866, redacted by Sharma P.V., 1st edition , New-Delhi, Chaukhambha publications, 161.

24. Prof Priya, V.S., \& Dr. Guru, P.S. (2002). Dhanwantari Nighantu, Karaviradi Varga, Shloka No- 137, Varanasi, Chaukhmbha Orientalia, Third edition, 146 .

25. Pandit, N., Raj, N., Karaviradi, V. (2003). Shloka No- 198-201, redacted by Indradeva Tripathi, Varanasi, Chaukhamba Krishnadas Academy, 337.

26. Acharya, C., Charaka, S. (2002). Sutrasthana $27^{\text {th }}$ chapter, Shloka No-115-117, Charaka Chandrika Hindi commentary of Agnivesha, edited by Dr. Bramhananda Tripathi, Chaukhamha Surabharati Prakashana, Varanasi, Reprint, 514.

27. Acharya, C., Charaka, S. (2002). Sutrasthana $25^{\text {th }}$ chapter, Shloka No-40, Charaka Chandrika Hindi commentary of Agnivesha, edited by Dr. Bramhananda Tripathi, Chaukhamha Surabharati Prakashana, Varanasi, Reprint, 454.

28. Acharya, K., Kaiyadeva, N., Oshadhi, V. (1979). Shloka No- 118, redacted by Sharma P.V., 1st edition , New-Delhi, Chaukhambha publications, 24.

29. Acharya Bhavamishra of Bhavaprakasha Nighantu. (2006). Pushpa Varga, Shloka No-36, by Dr. Bulusu Sitaram, Volume 1, Chaukhambha Orientalia, Varanasi, First edition, 324. 
30. Acharya, K., Kaiyadeva, N., Oshadhi, V. (1979). Arga, Shloka No- 286, redacted by Sharma P.V., 1st edition , New-Delhi, Chaukhambha publications, 55 .

31. Acharya, K., Kaiyadeva, N., Oshadhi, V. (1979). Shloka No- 418, redacted by Sharma P.V., 1st edition , New-Delhi, Chaukhambha publications, 77

32. Acharya, K., Kaiyadeva, N., Oshadhi, V. (1979). Shloka No- 1445, redacted by Sharma P.V., 1st edition , New-Delhi, Chaukhambha publications, 268.

33. Acharya Bhavamishra of Bhavaprakasha Nighantu, Pushpa Varga.(2006). Shloka No-3, by Dr. Bulusu Sitaram, Volume 1, Chaukhambha Orientalia, Varanasi, First edition, 316.

34. Acharya, K., Kaiyadeva, N., Oshadhi, V. (1979). Shloka No- 378, redacted by Sharma P.V., 1st edition , New-Delhi, Chaukhambha publications, 70 .

35. Acharya, K., Kaiyadeva, N., Oshadhi, V.(1979). Shloka No- 936, redacted by Sharma P.V., 1st edition , New-Delhi, Chaukhambha publications, 172

36. Acahrya, S., Sushruta, S., Purvardha, S.,(1978). $46^{\text {th }}$ chapter, Shloka No-281, Ayurveda Tatva Sandipika, Hindi commentary, edited by Kaviraja Dr. Ambikadatta Shastry, Chaukhamba Sanskrit Samsthan, Varanasi, Reprint, Page No-266.

37. Acharya, K., Kaiyadeva, N., Oshadhi, V. (1979). Shloka No- 684, redacted by Sharma P.V., 1st edition, New-Delhi, Chaukhambha publications, 126.

38. Prof Priya, V.S., \& Dr. Guru, P.S. (2002). Dhanwantari Nighantu, Chandanadi Varga, Shloka No- 12, Varanasi, Chaukhmbha Orientalia, Third edition, 93.

39. Acharya, K., Kaiyadeva, N., Oshadhi, V.(1979). Shloka No- 895, redacted by Sharma P.V., 1st edition , New-Delhi, Chaukhambha publications, 165.

40. Acahrya, S., Sushruta, S., Purvardha, S.(1989). $46^{\text {th }}$ chapter, Shloka No-284, Ayurveda Tatva Sandipika, Hindi commentary, edited by Kaviraja Dr. Ambikadatta Shastry, Chaukhamba Sanskrit Samsthan, Varanasi, Reprint, Page No-266.

41. Acharya, B., of Bhavaprakasha, N., Pushpa, V. (2006). Shloka No-54, by Dr. Bulusu Sitaram, Volume 1, Chaukhambha Orientalia, Varanasi, First edition, 330.

42. Pandit, N., Raj, N., Karaviradi, V.(2003). Shloka No- 101, redacted by Indradeva Tripathi, Varanasi, Chaukhamba Krishnadas Academy, 317.

43. Acharya, K., Kaiyadeva, N., Oshadhi, V. (1979). Shloka No- 1640, redacted by Sharma P.V., 1st edition , New-Delhi, Chaukhambha publications, 648.

44. Acahrya, S., Sushruta, S., Purvardha, S.(1987). $46^{\text {th }}$ chapter, Shloka No-288, Ayurveda Tatva Sandipika, Hindi commentary, edited by Kaviraja
Dr. Ambikadatta Shastry, Chaukhamba Sanskrit Samsthan, Varanasi, Reprint, Page No-266.

45. Acharya, B., of Bhavaprakasha, N., Pushpa, V. (2006). Shloka No-43, by Dr. Bulusu Sitaram, Volume 1, Chaukhambha Orientalia, Varanasi, First edition, 326.

46. Acharya, K., Kaiyadeva, Oshadhi, V.(1979). Shloka No- 31, redacted by Sharma P.V., 1st edition, New-Delhi, Chaukhambha publications, 9.

47. Pandit, N., Raj, N., Karaviradi, V.(2003). Shloka No- 57-58, redacted by Indradeva Tripathi, Varanasi, Chaukhamba Krishnadas Academy, 308.

48. Acharya, B., of Bhavaprakasha, N., Pushpa, V.(2006). Shloka No-32, by Dr. Bulusu Sitaram, Volume 1, Chaukhambha Orientalia, Varanasi, First edition, 323.

49. Acharya, B., of Bhavaprakasha, N., Pushpa, V. (2006). Shloka No-28, by Dr. Bulusu Sitaram, Volume 1, Chaukhambha Orientalia, Varanasi, First edition, 322.

50. Acharya, K., Kaiyadeva, N., Oshadhi, V., Shloka.(1979). No- 99, redacted by Sharma P.V., 1st edition , New-Delhi, Chaukhambha publications, 22.

51. Acharya, B., of Bhavaprakasha, N., Pushpa, V. (2006). Shloka No-56, by Dr. Bulusu Sitaram, Volume 1, Chaukhambha Orientalia, Varanasi, First edition, 331..

52. Acharya, B., of Bhavaprakasha, N., Pushpa, V., Shloka No-63, by Dr. Bulusu Sitaram, Volume 1, Chaukhambha Orientalia, Varanasi, First edition, 333.

53. Acharya, K., Kaiyadeva, N., Oshadhi, V.(1979). Shloka No- 307-311, redacted by Sharma P.V., 1st edition , New-Delhi, Chaukhambha publications, 59.

54. Acharya, K., Kaiyadeva, N., Oshadhi, V.(1979). Shloka No- 1072-1074, redacted by Sharma P.V., 1st edition , New-Delhi, Chaukhambha publications, 198.

55. Acharya, B., of Bhavaprakasha, N., Haritakyadi, V. (2006). Shloka No-187, by Dr. Bulusu Sitaram, Volume 1, Chaukhambha Orientalia, Varanasi, First edition, 173.

56. Prof Priya, V.S., \& Dr. Guru, P.S., Dhanwantari, N., Shatapushpadi, V.(2002). Shloka No- 48, Varanasi, Chaukhmbha Orientalia, Third edition, 78.

57. Acharya, K., Kaiyadeva, N., Oshadhi, V.(1979). Shloka No- 277, redacted by Sharma P.V., 1st edition , New-Delhi, Chaukhambha publications, 53.

58. Acharya, K., Kaiyadeva, N., Oshadhi, V.(1979). Shloka No- 883, redacted by Sharma P.V., 1st edition , New-Delhi, Chaukhambha publications, 163.

59. Acharya, K., Kaiyadeva, N., Oshadhi, V. (1979). Shloka No- 130, redacted by Sharma P.V., 1st edition , New-Delhi, Chaukhambha publications, 27. 
60. Prof Priya, V.S \& Dr. Guru, P.S., Dhanwantari, N., Karaviradi, V.(2002). Shloka No- 139, Varanasi, Chaukhmbha Orientalia, Third edition 2002, Page No- 146.

61. Acharya, K., Kaiyadeva, N., Oshadhi, V., Shloka.(1979). No- 463, redacted by Sharma P.V., 1st edition , New-Delhi, Chaukhambha publications, 85 .

62. Acharya, K., Kaiyadeva, N., Oshadhi, V., Shloka. (1979). No- 834, redacted by Sharma P.V., 1st edition , New-Delhi, Chaukhambha publications, 155.

63. Acharya, K., Kaiyadeva, N., Oshadhi, V., Shloka. (1979). No- 38, redacted by Sharma P.V., 1st edition , New-Delhi, Chaukhambha publications, 10 .

64. Acharya, K., Kaiyadeva, N., Oshadhi, V.(1979). Shloka No- 899, redacted by Sharma P.V., 1st edition , New-Delhi, Chaukhambha publications, 166.

65. Prof Priya, V. S., \& Dr. Guru, P.S., Dhanwantari, N., Chandanadi, V.(2002). Shloka No- 16, Varanasi, Chaukhmbha Orientalia, Third edition, 94.

66. Pandit, N., Raj, N., Karaviradi, V.(2003). Shloka No- 65-66, redacted by Indradeva Tripathi, Varanasi, Chaukhamba Krishnadas Academy, 310.

67. Acharya, B., of Bhavaprakasha, N., Pushpa, V. (2006). Shloka No-33-35, by Dr. Bulusu Sitaram, Volume 1, Chaukhambha Orientalia, Varanasi, First edition, 323.

68. Acharya, K., Kaiyadeva, N., Oshadhi, V.(1979). Shloka No- 356, redacted by Sharma P.V., 1st edition , New-Delhi, Chaukhambha publications, 67.

69. Acharya, B., Bhavaprakasha, N., Pushpa, V.(2006). Shloka No-57, by Dr. Bulusu Sitaram, Volume 1, Chaukhambha Orientalia, Varanasi, First edition, 331.

70. Acharya, K., Kaiyadeva, N., Oshadhi, V. (1979). Shloka No- 585, redacted by Sharma P.V., 1st edition , New-Delhi, Chaukhambha publications, 107.

71. Acharya, K., Kaiyadeva, N., Oshadhi, V.(1979). Shloka No- 23, redacted by Sharma P.V., 1st edition, New-Delhi, Chaukhambha publications, 7.

72. Acharya, K., Kaiyadeva, N., Oshadhi, V.(1979). Shloka No- 458, redacted by Sharma P.V., 1st edition , New-Delhi, Chaukhambha publications, 84.

73. Acharya, B., Bhavaprakasha, N., Pushpa, V. (2006). Shloka No-40, by Dr. Bulusu Sitaram, Volume 1, Chaukhambha Orientalia, Varanasi, First edition, 325.

74. Acharya, K., Kaiyadeva, N., Oshadhi, V.(1979). Shloka No- 261, redacted by Sharma P.V., 1st edition , New-Delhi, Chaukhambha publications, 50 .

75. Acharya, B., Bhavaprakasha, N., Pushpa, V.(2006). Shloka No-5, by Dr. Bulusu Sitaram, Volume 1,
Chaukhambha Orientalia, Varanasi, First edition, 330.

76. Acahrya, S., Sushruta, S., Purvardha, S.(1997). $46^{\text {th }}$ chapter, Shloka No-284, Ayurveda Tatva Sandipika, Hindi commentary, edited by Kaviraja Dr. Ambikadatta Shastry, Chaukhamba Sanskrit Samsthan, Varanasi, Reprint, Page No-266.

77. Acharya, K., Kaiyadeva, N., Oshadhi, V. (1979). Shloka No- 876, redacted by Sharma P.V., 1st edition , New-Delhi, Chaukhambha publications, 162.

78. Acharya, K., Kaiyadeva, N., Oshadhi, V. (1979). Shloka No- 666, redacted by Sharma P.V., 1st edition , New-Delhi, Chaukhambha publications, 123.

79. Acharya, B., of Bhavaprakasha, N., Pushpa, V. (2006). Shloka No-29-30, by Dr. Bulusu Sitaram, Volume 1, Chaukhambha Orientalia, Varanasi, First edition, 322.

80. Pandit, N., Raj, N., Karaviradi, V. (2003). Shloka No- 98, redacted by Indradeva Tripathi, Varanasi, Chaukhamba Krishnadas Academy, 316.

81. Prof Priya, V.S \& Dr. Guru P.S. (2002). Dhanwantari Nighantu, Chandanadi Varga, Shloka No- 40, Varanasi, Chaukhmbha Orientalia, Third edition, 98.

82. Acharya, K., Kaiyadeva, N., Oshadhi, Varga. (1979). Shloka No- 1127 redacted by Sharma P.V., 1 st edition , New-Delhi, Chaukhambha publications, 208.

83. Acharya, K., Kaiyadeva, N., Oshadhi, V.(1979). Shloka No- 850, redacted by Sharma P.V., 1st edition , New-Delhi, Chaukhambha publications, 158.

84. Acharya, K., Kaiyadeva, N., Oshadhi, V.(1979). Shloka No- 12, redacted by Sharma P.V., 1st edition, New-Delhi, Chaukhambha publications, 6.

85. Acahrya, S., Sushruta, S., Purvardha, S.(2006). $46^{\text {th }}$ chapter, Shloka No-281, Ayurveda Tatva Sandipika, Hindi commentary, edited by Kaviraja Dr. Ambikadatta Shastry, Chaukhamba Sanskrit Samsthan, Varanasi, Reprint, Page No-266.

86. Acharya, C., Charaka, S.(2002). Sutrasthana $27^{\text {th }}$ chapter, Shloka No-104, Charaka Chandrika Hindi commentary of Agnivesha, edited by Dr. Bramhananda Tripathi, Chaukhamha Surabharati Prakashana, Varanasi, Reprint, 513.

87. Prof Priya, Vrat, S., \& Dr. Guru, P.S., Dhanwantari, N.(2002). Amradi Varga, Shloka No140, Varanasi, Chaukhmbha Orientalia, Third edition, 175.

88. Acharya, B., Bhavaprakasha, N., Pushpa, V.(2006). Shloka No-23, by Dr. Bulusu Sitaram, Volume 1, Chaukhambha Orientalia, Varanasi, First edition, 320.

89. Acharya, K., Kaiyadeva, N., Oshadhi, V. (1979). Shloka No- 863, redacted by Sharma P.V., 1st edition , New-Delhi, Chaukhambha publications, 160. 
90. Acharya, K., Kaiyadeva, N., Oshadhi, V. (1979). Shloka No- 807, redacted by Sharma P.V., 1st edition , New-Delhi, Chaukhambha publications, 150.

91. Acharya, B., Bhavaprakasha, N., Vatadi, V.(2006). Shloka No-78, by Dr. Bulusu Sitaram, Volume 1, Chaukhambha Orientalia, Varanasi, First edition, 361.

92. Acharya, K., Kaiyadeva, N., Oshadhi, V.(1979). Shloka No- 812, redacted by Sharma P.V., 1st edition , New-Delhi, Chaukhambha Publications, 151
93. Acharya, B., Bhavaprakasha, N., Guduchadi, V.(2006). Shloka No-105, by Dr. Bulusu Sitaram, Volume 1, Chaukhambha Orientalia, Varanasi, First edition, 255.

94. Acharya, K., Kaiyadeva, N., Oshadhi, V.(1979). Shloka No- 748, redacted by Sharma P.V., 1st edition , New-Delhi, Chaukhambha publications, 138

95. Acharya, K., Kaiyadeva, N., Oshadhi, V. (1979). Shloka No- 748, redacted by Sharma P.V., 1st edition , New-Delhi, Chaukhambha publications, 138. 